\title{
Adenylate Cyclase of Human Fat Cell Ghosts
}

\author{
STIMULATION OF ENZYME ACTIVITY BY PARATHYROID HORMONE
}

\author{
HORST KATHER and BERND SimON \\ From the Klinisches Institut für Herzinfarktforschung an der Medizinischen Universitätsklinik \\ Heidelberg, D-69 Heidelberg, West Germany
}

\begin{abstract}
A B S T RACT Some of the effects of native bovine parathyroid hormone and of the synthetic aminoterminal 1-34 fragment on the adenylate cyclase activity of human fat cell ghosts were studied. Saturating concentrations of both hormone preparations caused a significant increase of enzyme activity by about 200-300\%. Guanosine 5'-triphosphate (0.1 $\mathrm{mM}$ ) inhibited basal enzyme activity but had no substantial effect on parathyroid hormone-stimulated enzyme activity. The guanosine 5'-triphosphate analogue, 5'-guanylyl-imidodiphosphate, produced about a threefold enhancement of basal and parathyroid hormone-stimulated enzyme activities under standard conditions $\left(5 \mathrm{mM} \mathrm{Mg}^{2+}, 1 \mathrm{mM}\right.$ ATP, $\mathrm{pH}$ 8.0, $\left.30^{\circ} \mathrm{C}\right)$.

Activation by parathyroid hormone was not influenced by $\beta$-adrenergic blockade in contrast to stimulation by epinephrine. The sensitivity of the enzyme system to the native and the synthetic parathyroid hormone was, however, abolished after pretreatment of the fat cells with trypsin $(1 \mathrm{mg} / \mathrm{ml})$. The stimulatory effects of epinephrine and $\mathrm{NaF}$ were not affected by pretreatment with trypsin.

The results suggest that human fat cells, like rat adipocytes, contain a multireceptor-coupled adenylate cyclase.
\end{abstract}

\footnotetext{
Received for publication 26 October 1976 and in revised form 24 January 1977.
}

\section{INTRODUCTION}

The fat cell adenylate cyclase is a plasma membrane-bound enzyme which is supposed to play a central role in the stimulation of lipolysis by hormones (1). The rat fat cell enzyme reacts to a variety of hormones including catecholamines and peptide hormones such as ACTH, glucagon, and secretin (2-4). By contrast, only catecholamines have been found to be capable in activating the human enzyme system (5-10). In this communication it is shown that parathyroid hormone $(\mathrm{PTH})^{1}$ can activate the adenylate cyclase system of human fat cell ghosts via binding to an individual receptor separable from adrenergic receptor sites.

\section{METHODS}

Source of biopsies. Biopsies of subcutaneous adipose tissue were obtained from 10 patients undergoing surgical treatment. No attempt was made to select the patients on the basis of age, sex, weight, or disease, except that cachectic persons were excluded. The patients were operated on after an overnight fast. Anesthesia was induced with a short-acting barbiturate and maintained with halothane, nitrous oxide, and oxygen. The biopsies were usually obtained after the skin incision.

\footnotetext{
${ }^{1}$ Abbreviations used in this paper: cAMP, 3',5'-cyclic AMP; GMP(PNP), 5'-guanylyl-imidodiphosphate; PTH, native bovine parathyroid hormone; 1-34 PTH, synthetic amino-terminal 1-34 PTH fragment.
} 
Preparation of fat cell ghosts. Adipose tissue was cut into 20-25-mg fragments and fat cells were isolated essentially according to Rodbell (11), except that higher concentrations of collagenase $(3 \mathrm{mg} / \mathrm{ml})$ were used. When present, trypsin $(1 \mathrm{mg} / \mathrm{ml})$ was included during collagenase digestion. Hen egg white trypsin inhibitor $(0.1 \mathrm{mg} / \mathrm{ml})$ was added to the washing media and the assay medium in these experiments.

Fat cell ghosts were prepared according to the same prescription (11). The lysing medium contained $2.5 \mathrm{mM}$ $\mathrm{MgCl}_{2}, 2.5 \mathrm{mM} \mathrm{ATP}, 0.1 \mathrm{mM} \mathrm{CaCl}, 1.0 \mathrm{mM} \mathrm{KHCO}$, and Tris- $\mathrm{HCl}, \mathrm{pH} 7.6,(2.0 \mathrm{mM})$. The ghosts were suspended in a medium containing $0.1 \mathrm{mM} \mathrm{KHCO}_{3}$ and $25 \mathrm{mM}$ mercaptoethanol in a final concentration of $0.25-2.5 \mathrm{mg}$ protein $/ \mathrm{ml}$.

Adenylate cyclase assay. The adenylate cyclase activity was determined according to Salomon et al. (12) at $30^{\circ} \mathrm{C}$. The incubation mixture contained $25 \mathrm{mM}$ Tris $-\mathrm{HCl}$, $\mathrm{pH} 8.0,5 \mathrm{mM} \mathrm{MgCl} 2,20 \mathrm{mM}$ creatine phosphate, $100 \mathrm{U} / \mathrm{ml}$

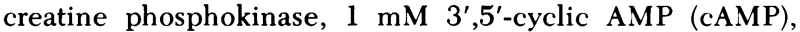
and $1 \mathrm{mM} \alpha-{ }^{32} \mathrm{P}$-ATP $(40-50 \mathrm{cpm} / \mathrm{pmol})$.

The reaction was initiated by addition of $20 \mu$ l of suspended ghosts (1-20 $\mu \mathrm{g}$ of ghost protein) and was terminated by addition of $0.1 \mathrm{ml}$ of stopping solution composed of $2 \%$ (wt/vol) lauryl sulfate, $1 \mathrm{mM}$ cAMP, and $40 \mathrm{mM}$ ATP.

Cyclic ${ }^{32} \mathrm{P}$-cAMP was purified by column chromatography with Dowex AG-50 W-X4 (Dow Chemical Co., Midland, Mich.) and neutral alumina (12). The protein content of the samples was determined according to Lowry et al. (13) with bovine serum albumin as standard. Data are given as nanomoles of cAMP formed per milligram of protein per 15 min. Statistical analysis was by the Wilcoxon test for paired samples. $\alpha^{-32} \mathrm{P}$-ATP $(2-6 \mathrm{Ci} / \mathrm{mmol})$ and $\left[{ }^{3} \mathrm{H}\right] \mathrm{cAMP}(27$ $\mathrm{Ci} / \mathrm{mmol}$ ) were purchased from The Radiochemical Centre, Amersham, England. Epinephrine-bitartrate was from Merck AG., Darmstadt, W. Germany; propranolol-hydro-

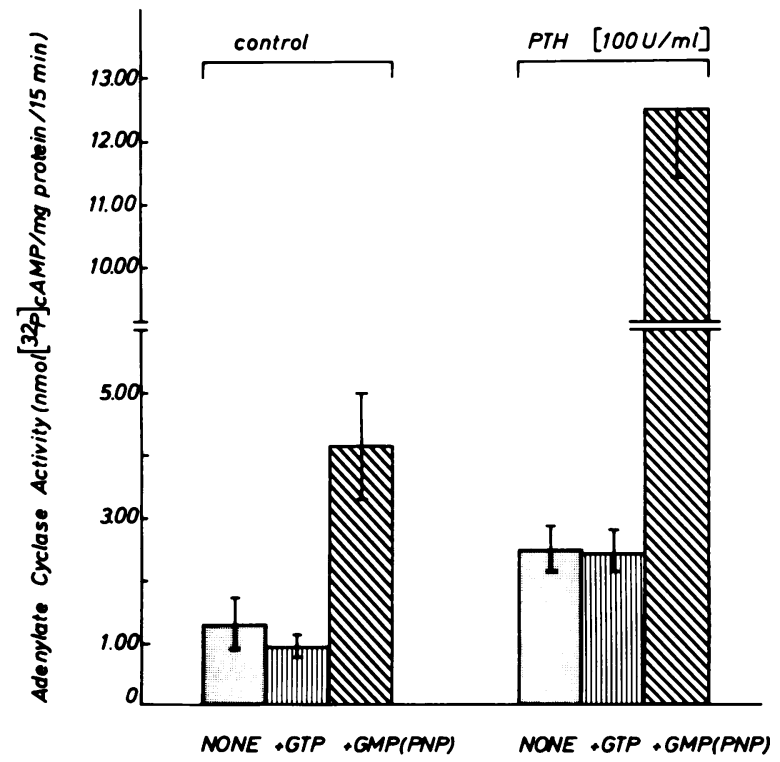

FIGURE 1 Effects of the native bovine PTH on the human fat cell adenylate cyclase in the presence and absence of guanosine 5'-triphosphate (GTP) and GMP(PNP) (each 0.1 $\mathrm{mM})$. Results are mean $\pm \mathrm{SEM}$ of seven experiments carried out with ghosts from different patients.

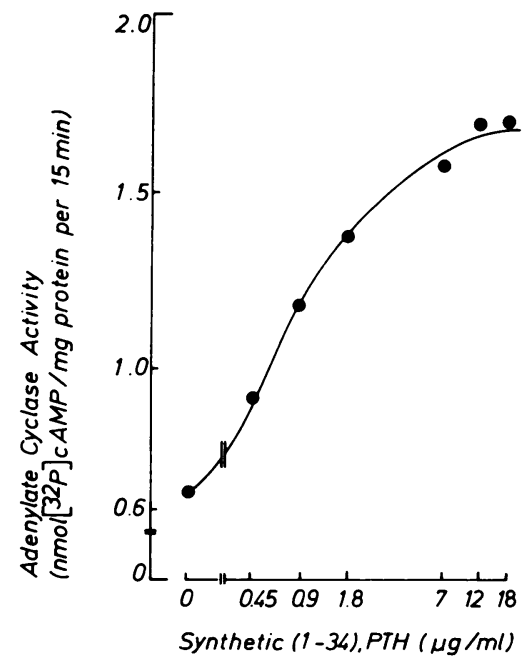

FIGURE 2 Log dose-response curve of the human fat cell adenylate cyclase for synthetic 1-34 PTH.

chloride was from Boehringer Ingelheim, Ingelheim W. Germany; and enzymes, coenzymes, and nucleotides were from Boehringer Mannheim, G.m.b.H., Mannheim, W. Germany. Synthetic ACTH was purchased from Ciba Geigy G.m.b.H., Wehrbaden, W. Germany; glucagon (insulin-free) was from Eli Lilly G.m.b.H., Bad Homburg, W. Germany. PTH $(500 \mathrm{U} / \mathrm{mg})$ was obtained from Hormonchemie, München, W. Germany and synthetic amino-terminal 1-34 PTH fragment (1-34 PTH) (lot 80454, 2,770 U/mg) was purchased from Beckman Instruments, Inc., Fullerton, Calif. Both hormone preparations were freshly dissolved in Tris- $\mathrm{HCl}$, ( $25 \mathrm{mM}, \mathrm{pH} 8.0$ ) immediately before use.

\section{RESULTS}

Fig. 1 illustrates the stimulation of the human fat cell adenylate cyclase by the native bovine $\mathrm{PTH}$ $(100 \mathrm{U} / \mathrm{ml})$ in the absence or presence of guanosine 5 '-triphosphate and 5'-guanylyl-imidodiphosphate [GMP(PNP)], respectively. The results are mean \pm SEM of seven separate experiments carried out with ghosts from different patients.

Basal enzyme activity averaged $1.30 \mathrm{nmol}$ cAMP formed per $\mathrm{mg}$ protein/15 $\mathrm{min}$ in these experiments. Guanosine 5'-triphosphate $(0.1 \mathrm{mM})$ significantly depressed basal enzyme activity $(P \leq 0.05)$. The guanine nucleotide analogue GMP(PNP) $(0.1 \mathrm{mM})$, however, caused a marked increase of basal enzyme activity by about $300 \%(P \leq 0.05)$ as previously reported $(9,10)$. The activities of the enzyme in its GMP(PNP)activated state were in the same range as normally observed in the presence of epinephrine (10) but exceeded the increase of cAMP-formation induced by PTH.

Native bovine PTH $(100 \mathrm{U} / \mathrm{ml})$ caused a significant $(P \leq 0.05)$ increase of enzyme activity by about $200 \%$. Guanosine 5'-triphosphate had no substantial 
TABLE I

Effects of Epinephrine (0.5 $\mathrm{mM}), 1-34 \mathrm{PTH}(18 \mu \mathrm{g} / \mathrm{ml})$, $\mathrm{NaF}(20 \mathrm{mM})$, ACTH $(0.1 \mathrm{mg} / \mathrm{ml})$, and Glucagon $(0.1 \mathrm{mg} / \mathrm{ml})$ on the Adenylate ('yclase Activity of Ghosts from Untreated and Trypsinized Fat Cells*

\begin{tabular}{lcc}
\hline \multirow{2}{*}{ Additions } & \multicolumn{2}{c}{ Adenylate cyclase activity } \\
\cline { 2 - 3 } None & Control & Trypsin-treated \\
\hline ACTH & $0.9 \pm 0.05$ & $0.8 \pm 0.05$ \\
Glucagon & $0.95 \pm 0.08$ & N.D. $\S$ \\
Propranolol & $1.0 \pm 0.10$ & N.D. \\
Epinephrine & $0.96 \pm 0.07$ & N.D. \\
1-34 PTH & $5.0 \pm 0.35$ & $4.9 \pm 0.40$ \\
Epinephrine & $3.4 \pm 0.30$ & $1.0 \pm 0.07$ \\
+ propranolol & $0.95 \pm 0.06$ & N.D. \\
1-34 PTH & & \\
+ propranolol & $3.50 \pm 0.25$ & N.D. \\
NaF & $9.0 \pm 0.7$ & $9.3 \pm 0.60$ \\
\hline
\end{tabular}

* Trypsin ( $1 \mathrm{mg} / \mathrm{ml})$ was included during collagenase digestion.

\$ Values are mean \pm SD of triplicate determinations.

$\S$ N.D., not determined.

effect on the enzyme in its PTH-liganded state. Combination of PTH and GMP(PNP) resulted in an increase by about $300 \%$ above GMP(PNP)-activated levels $(P \leq 0.05)$.

Depicted in Fig. 2 is a typical log dose-response curve for the pure synthetic 1-34 PTH fragment on the human fat cell adenylate cyclase. The concentration of 1-34 PTH producing half-maximal stimulation was about $1.1 \mu \mathrm{g} / \mathrm{ml}$ corresponding to about $4 \mathrm{U} / \mathrm{ml}$. Maximal response was observed at a 1-34 PTH concentration of about $12 \mu \mathrm{g} / \mathrm{ml}$.

Table I compares the effects of ACTH, glucagon, 1-34 PTH, and epinephrine on the adenylate cyclase activity of human fat cell ghosts prepared from untreated or trypsinized fat cells. In ghosts from untreated controls ACTH $(0.1 \mathrm{mg} / \mathrm{ml})$ and glucagon $(0.1 \mathrm{mg} / \mathrm{ml})$ were ineffective in stimulating the enzyme system. 1-34 PTH $(12 \mu \mathrm{g} / \mathrm{ml})$, epinephrine $(0.1 \mathrm{mM})$, and $\mathrm{NaF}(20 \mathrm{mM})$ caused about 3-, 4-, and 10-fold increases of enzyme activity in this membrane preparation. The stimulatory action of epinephrine was completely inhibited by $0.01 \mathrm{mM}$ propranolol. This $\beta$-blocking agent had no effect on the 1-34 PTHactivated rates of cAMP formation.

Pretreatment of fat cells with trypsin $(1 \mathrm{mg} / \mathrm{ml})$ had no substantial effect on basal enzyme activity but resulted in an almost complete abolishment of 1-34 PTH stimulation. The responsiveness to epinephrine and $\mathrm{NaF}$ was not altered under these conditions.

\section{DISCUSSION}

The existence of an epinephrine-sensitive adenylate cyclase in human fat cell ghosts has been demonstrated in several recent reports (5-10). It has been shown that parathyroid hormone can promote lipolysis in human adipocytes $(14,15)$. To our knowledge, however, a direct action of PTH on the human fat cell adenylate cyclase has not yet been reported. Our results are in good agreement with the concept that the effects of PTH on human adipose tissue are mediated via activation of the membrane-associated adenylate cyclase system. The effective concentrations of PTH are in the same range as those reported to be necessary to activate lipolysis in intact adipocytes in vitro $(14,15)$. These hormone concentrations are unphysiologically high. It is a common experience, however, to find the adenylate cyclase system in vitro much less sensitive to hormones than the intact target tissue in vivo. The specificity of PTH action is further underscored by the observation that even higher concentrations of other peptide hormones such as ACTH and glucagon were ineffective in stimulating the enzyme system.

Since activation by PTH was not inhibited by $\beta$ adrenergic blockade with propranolol, it is obvious that this hormone acts at sites distinct from the $\beta$-adrenergic receptor. The absence of PTH effect after pretreatment with trypsin has also been reported from membrane preparations of kidney (16) and skeletal tissue (17). This observation implies that PTH acts via specific membrane proteins not essential for catalytic activity, catecholamine binding, or NaFstimulation. Thus, our results support the existence of a multireceptor-coupled adenylate cyclase in human fat cell ghosts.

\section{REFERENCES}

1. Robison, G. A., R. W. Butcher, and E. W. Sutherland. 1971. Lipolysis in adipose tissue. In Cyclic AMP. G. A. Robison, R. W. Butcher, and E. W. Sutherland, editors. Academic Press, Inc., New York. 285-316.

2. Birnbaumer, L., S. L. Pohl, and M. Rodbell. 1969. Adenyl cyclase in fat cells. I. Properties and the effects of adrenocorticotropin and fluoride. J. Biol. Chem. 244: 3468-3476.

3. Birnbaumer, L., and M. Rodbell. 1969. Adenyl cyclase in fat cells. II. Hormone receptors. J. Biol. Chem. 244: 3477-3482.

4. Rodbell, M. 1971. Hormones, receptors and adenyl cyclase activity in mammalian cells. In Colloquium on the Role of Adenyl Cyclase and cyclic $3^{\prime} 5^{\prime}$-AMP in 
Biological Systems. Fogarty International Center, Government Printing Office. 88-95.

5. Poupon, R. 1975. Activity of human adenylate cyclase from human fat cell membranes. Biomedicine (Paris). 23: 438-442.

6. Burns, T. W., and P. E. Langley. 1975. The effect of alpha and beta adrenergic receptor stimulation on the adenylate cyclase activity of human adipocytes. J. Cyclic Nucl. Res. 1: 321-328.

7. Cooper, B., J. S. Partilla, and R. I. Gregerman. 1975. Adenylate cyclase of human fat cells. Expression of epinephrine-sensitive activation revealed by $5^{\prime}$ guanylyl-imidodiphosphate. J. Clin. Invest. 56: 13501353.

8. Kather, H., G. Simon-Crisan, and B. Simon. 1976. Inhibition of human fat cell adenylate cyclases by clofibrate. Horm. Metab. Res. 8: 246-247.

9. Cooper, B., J. S. Partilla, and R. I. Gregerman. 1976. Human fat cell adenylate cyclase. Enzyme characterization and guanine nucleotide effects on epinephrine responsiveness in cell membranes. Biochim. Biophys. Acta. 445: 246-258.

10. Kather, H., and B. Simon. 1976. Catecholamine-sensitive adenylate cyclase of human fat cell ghosts. Characteristics of the GMP(PNP)-liganded state. Clin. Chim. Acta. 73: 497-504.
11. Rodbell, M. 1972. Methods for the isolation of rat liver plasma membranes and fat cell "Ghosts"; an assay method for adenylate cyclase. In Methods of Cyclic Nucleotide Research. M. Chasin, editor. Marcel Dekker, Inc., New York. 101-124.

12. Salomon, Y., C. Londos, and M. Rodbell. 1974. A highly sensitive adenylate cyclase assay. Anal. Biochem. 58: 541-548.

13. Lowry, O. H., N. J. Rosebrough, A. L. Farr, and R. J. Randall. 1951. Protein measurement with the Folin phenol reagent. J. Biol. Chem. 193: 265-275.

14. Gozariu, L., K. Forster, J. D. Faulhaber, H. Minne, and R. Ziegler. 1974. Parathyroid hormone and calcitonin: Influences upon lipolysis of human adipose tissue. Horm. Metab. Res. 6: 243-245.

15. Sinha, T. K., P. Thajchayapong, S. F. Queener, D. O. Allen, and N. Bell. 1976. On the lipolytic action of parathyroid hormone in man. Metab. Clin. Exp. 25: $251-260$.

16. Chase, L. R., 1975. Selective proteolysis of the receptor for parathyroid hormone in renal cortex. Endocrinology. 96: 70-76.

17. Chase, L. R., and K. A. Obert. 1975. Selective proteolysis of the receptor for parathyroid hormone in skeletal tissue. Metab. Clin. Exp. 24: 1067-1071. 